\title{
“The Long Journey Home?" Sebuah Analisis Teologis terhadap Metode Berteologi Thomas C. Oden
}

\author{
Yudi Jatmiko* \\ *Penulis adalah Youth Pastor di Gereja Presbyterian Bukit Batok, Singapore. \\ Email: yudi3036@yahoo.com
}

\begin{abstract}
Abstrak: Teologi ialah disiplin ilmu yang berkembang secara dinamis, majemuk, dan progresif. Metode berteologi pada satu kurun waktu tertentu umumnya menjadi bagian dari dialektika tiada berujung metode berteologi baru yang dihasilkan. Tidak heran berbagai sintesis teologis diformulasikan demi mengarah kepada teologi yang prospektif. Anehnya, alih-alih bersifat prospektif, metode berteologi Oden bersifat retrospektif. Oden kembali kepada masa lalu, tepatnya kepada tulisan para bapa gereja. Yang menjadi masalah ialah apakah proposal Oden yang tertuang dalam metode berteologinya ini adalah proposal yang relevan, khususnya dalam konteks teologi yang majemuk di abad 21? Ini yang menjadi fokus penelitian penulis. Tulisan ini akan memaparkan dan menganalisis tiga metode yang amat kentara dalam metode berteologi Oden, yaitu teologi yang kembali kepada tulisan patristik, berakar pada warisan sejarah kekristenan Afrika awal, dan bermuara kepada penggembalaan. Melaluinya, penulis berharap mendapatkan analisis teologis yang objektif dan kontributif. Ini dikarenakan terlepas dari gerak prospektif metode berteologi pada umumnya, penulis meyakini bahwa metode berteologi Oden yang retrospektif tetap memiliki relevansi signifikan bagi konteks teologi abad 21.
\end{abstract}

Kata-kata kunci: Metode Berteologi, Tulisan Patristik, Teologi Thomas C. Oden, Kekristenan Afrika Awal

Abstract: Theology is a discipline that develops dynamically and progressively with complexity. The development of theological method in a certain time period generally becomes part of the dialectic without a clear maturation of the new method. No wonder various theological syntheses are formulated that lead to new prospective theologies. Interestingly, instead of being prospective, Oden's theological method is retrospective. Oden has returned to the past-more precisely to the writings of the church fathers. The problem presented is whether or not Oden's proposal, contained in his theological method, is a relevant proposal. Especially as it is formulated in the plurality of the theological context in the 21st century. This is the focus of the author's research. This paper will describe and analyze the three most obvious aspects of Oden's method of theology, namely a theology that returns to the patristic writings, is rooted in the historical legacy of early African Christianity, and pertains to pastoral shepherding. Through this study, the author hopes to contribute to objective theological analysis in the contemporary setting by developing a study on Oden's retrospective theological method which has significant relevance for the 21st century theological context.

Keywords: Theological Method, Patristic Literature, Theology of Thomas C. Oden, Early African Christianity 


\section{Pendahuluan}

Teologi sebagai sebuah scientia-yang-bermuara-pada-sapientia ${ }^{1}$ ialah disiplin ilmu yang berkembang secara dinamis, majemuk, dan progresif. $^{2}$ Metode berteologi pada satu kurun waktu tertentu umumnya menjadi bagian dari dialektika tiada berujung metode berteologi baru yang dihasilkan. ${ }^{3}$ Selain itu, karena "the future is not closed to theological wisdom, coherence or system," teologi juga menjadi disiplin ilmu yang prospektif, artinya mengarah kepada masa depan di mana "the current fusing of theological styles is an interesting harbinger of new directions in theological method." Tidak heran berbagai sintesis teologis diformulasikan demi mengarah kepada teologi yang prospektif ini. Anehnya, tidak demikian dengan Thomas C. Oden.

Alih-alih bersifat prospektif, metode berteologi Oden bersifat retrospektif. Oden kembali kepada masa lalu, tepatnya kepada tulisan para bapa gereja. ${ }^{6}$ Di hadapan Evangelical

${ }^{1}$ David K. Clark dengan indah merumuskan bahwa "evangelical theology is scientia - the knowledge of God. . . . When this theology reaches full bloom, it blossoms into sapientia - the wisdom of God... . This is what it means to know and love the true and living God" (To Know and Love God, ed. John S. Feinberg [Wheaton: Crossway, 2003], 424). Cetak tegak ada pada teks aslinya.

${ }^{2}$ Kedinamisan, kemajemukan, dan progresivitas teologi tampak jelas dalam perkembangan metode berteologi yang kian beragam. Mengenai hal ini, Paul L. Allen mengamati bahwa "there continues to grow a diversity of theological methods, owing to different interpretations of theological sources, despite more recent attempts to render theological coherence through fresh reconsiderations" (Theological Method: A Guide for the Perplexed [London: T\&T Clark, 2012], 2).

${ }^{3}$ Senada dengan hal ini, Allen menyatakan bahwa "what is still relatively new, however, is the extent to which the viability of certain theological sources is contested" (ibid.). Pada bagian lain, ia menyimpulkan bahwa "the nature of the theological task and criteria of judgement in theological claims are all up for scrutiny and debate in theology" (ibid., 228).

${ }^{4}$ Ibid.

${ }^{5}$ Ibid.

${ }^{6}$ Yang penulis maksud dengan "tulisan para bapa gereja" ialah segala tulisan yang mengacu kepada warisan teologi patristik yang menjadi consensus patrum dan mengacu kepada teologi dan tradisi apostolik (bdk. catatan
Theological Society, ia menyatakan tujuannya dengan jelas demikian:

I want to reaffirm solemn commitments made at its beginning: to make no new contribution to theology, and to resist the temptation to prefer modern writers less schooled in the whole counsel of God than the best ancient classic exegetes. I seek quite simply to express the one mind of the believing Church that has been ever attentive to that apostolic teaching to which consent has been given by Christian believers everywhere, always, and by all. ${ }^{7}$

Oden tidak ingin memberikan sebuah kontribusi baru dalam teologi. Apa yang berusaha ia capai ialah sebuah konsensus teologis yang umumnya disepakati bersama oleh orang percaya di segala waktu dan tempat. Bagi Oden, ketimbang merujuk kepada para penulis modern, ia langsung kembali ke akarnya, yaitu teologi patristik. Yang menjadi masalah ialah apakah proposal Oden yang tertuang dalam metode berteologinya ini adalah proposal yang relevan, khususnya dalam konteks teologi yang majemuk di abad 21? Ini yang menjadi fokus penelitian penulis.

Tulisan ini berusaha: pertama, memaparkan metode berteologi Oden. Pada bagian ini penulis akan membatasi hanya kepada tiga metode yang amat kentara dalam metode berteologinya, yaitu teologi yang kembali kepada tulisan patristik, berakar pada warisan sejarah kekristenan Afrika awal, dan bermuara kepada penggembalaan. Pembatasan ini dilakukan dengan mempertimbangkan dua hal, yaitu keterbatasan ruang penulisan dan kedalaman fokus penelitian; kedua, menganalisis metode berteologi Oden. Di sini penulis akan berusaha menyajikan berbagai pandangan, baik yang mendukung maupun menentang proposal yang Oden tawarkan

kaki 22). Dalam makalah ini, penulis tidak akan menggunakan istilah "paleo-orthodoxy" tetapi penulis akan menyebut dengan beberapa frasa seperti "tulisan bapa gereja," "tulisan patristik," atau "teologi patristik" untuk lebih memperjelas makna.

7"The Long Journey Home," Journal of the Evangelical Theological Society 34, no. 1 (March 1991): 79. 
berkaitan dengan tiga metode berteologinya di atas. Melaluinya, penulis berharap mendapatkan analisis teologis yang objektif dan kontributif. Ini dikarenakan terlepas dari gerak prospektif metode berteologi pada umumnya, penulis meyakini bahwa metode berteologi Oden yang retrospektif tetap memiliki relevansi signifikan bagi konteks teologi abad 21 .

\section{Metode Berteologi Thomas C. Doen}

Oden sendiri tidak menulis sebuah buku yang menjelaskan metode berteologinya dengan spesifik. Namun, metode (atau metodemetode) tersebut amat jelas dalam tulisantulisannya. Tiga hal yang amat kentara ialah kembali kepada tulisan patristik, berakar pada warisan sejarah kekristenan Afrika awal, dan bermuara kepada penggembalaan. Ketiganya akan diuraikan masing-masing dalam bagian ini.

\section{Kembali kepada Tulisan Patristik}

Yang paling kentara dari metode berteologi Oden ialah semangatnya untuk kembali kepada tulisan para bapa gereja. Sebagai seorang teolog yang tumbuh dan dibesarkan dalam warisan teologi modern, Oden terbiasa dengan pemikiran Paul Tillich, Martin Heidegger, dan di atas semuanya, Rudolf Bultmann. ${ }^{8}$ Namun perubahan hidup secara teologis terjadi ketika Oden mengikuti saran dari Will Herberg untuk kembali kepada sumber patristik demi mendapatkan bangunan teologi yang sehat. ${ }^{9}$ Sejak itu, Oden menyadari kekeliruan teologinya selama ini dan mengabdikan hidupnya untuk menggali kekayaan tulisan patristik.

Mengenai tulisan patristik, Oden sendiri mengakui bahwa "my major purpose . . is to

${ }^{8}$ Christopher A. Hall, "Back to the Fathers," Christianity Today 21 Oktober 2011 http://www.christianitytoday. com/ct/2011/octoberweb-only/back-fathers.html (diakses 2 April 2015).

${ }^{9}$ Menurut Oden, perubahan teologinya terjadi sejak tahun 1971 (lih. Christopher A. Hall, "Introduction," dalam Ancient \& Postmodern Christianity: Paleo-Orthodoxy in the $21^{\text {st }}$ Century [eds. Kenneth Tanner and Christopher A. Hall; Downers Grove: InterVarsity, 2002], 9). allow the ancients to speak for themselves, and let their relevance be judged by those who wish to put their vision into actual practice." 10 Yang Oden maksudkan dengan "ancients" adalah berbagai tulisan bapa gereja yang mengacu pada pengajaran rasuli. Nantinya, Oden juga menggunakan sumber-sumber di luar tulisan bapa gereja namun yang memiliki konsensus sejarah dan teologis yang sama dengan yang dipercayai oleh bapa-bapa gereja. Mengenai hal ini, Oden mengatakan:

The weighting of references may be compared to a pyramid of sources with Scripture as the foundational base, then the early Christian writers, first pre-Nicene then post-Nicene, as the supporting mass or trunk, then the best of medieval followed by centrist Reformation writers at the narrowing center, and more recent interpreters at the smaller, tapering apex, but only those who grasp and express the anteceding mind of the believing historic Church. ${ }^{11}$

Bagi Oden, Alkitab jelas menjadi dasar yang fondasional. Namun, tulisan patristik yang mengacu kepada pengajaran rasuli adalah kekayaan teologis yang seharusnya menjadi rujukan dan pemersatu berbagai pemikiran teologis yang ada. ${ }^{12}$ Inilah pola yang terus berulang dalam tulisan-tulisan teologis Oden.

${ }^{10}$ The Good Works Reader (Grand Rapids: Eerdmans, 2007), 1.

11“"The Long Journey Home," 81.

${ }^{12}$ Mengenai hal ini, Oden mengatakan bahwa " $m y$ basic purpose is to set forth an ordered view of the faith of the Christian community upon which there has generally been substansial agreement between the traditions of East and West, including Catholic, Protestant, and Orthodox" (The Living God [New York: Harper \& Row, 1987], ix; bandingkan cara Oden menggunakan tulisan patristik untuk mengatasi polemik gender dalam "On Women and Men Working Together in the Church: Who Will Lead Us? Surely the One Whom the Spirit Gifts," Evangelical Review of Theology 26, no. 2 [April 2002]: 119-135). 
Pola ini terlihat paling tidak dalam tiga aspek besar tulisannya, yaitu sistematika, ${ }^{13}$ biblika, ${ }^{14}$ dan pastoral. ${ }^{15}$ Dalam hal teologi sistematika, Oden memulainya dengan menunjukkan bahwa tugas utama dari teologi bukanlah demonstrasi logika atau pun proklamasi normatif dari kebenaran Kristen, melainkan sebuah "clarification of faith's understanding of itself and its ground." 16 Klarifikasi ini adalah tugas rasional teologi yang tidak dapat dilepaskan dari aspek iman. Oden tidak mendikotomikan antara iman dan rasio. Aspek iman yang dipelihara dalam teologi bukanlah sebuah pengorbanan intelektual. ${ }^{17}$ Sebaliknya, mengikuti jejak Anselmus, baginya teologi harus merupakan "fides quaerens

\footnotetext{
${ }^{13}$ Sistematika teologi Oden terlihat khususnya dalam tiga volume sistematika teologinya, yaitu The Living God, The Word of Life, dan Life in the Spirit yang Oden sebut sebagai "the triune theme" ("The Long Journey Home," 78). Oleh karena keterbatasan ketersediaan sumber, penulis hanya akan menggunakan The Living God dalam makalah ini.
}

${ }^{14}$ Misalnya dalam Thomas C. Oden, "Without Excuse: Classic Christian Exegesis of General Revelation," Journal of the Evangelical Theological Society 41, no. 1 (March 1998): 55-68. Dengan menggunakan Roma 1:18-22 sebagai studi kasus, Oden menunjukkan bagaimana teologi patristik menafsirkan konsep wahyu umum dalam teks tersebut. Tanpa keraguan Oden menyatakan maksudnya, yaitu "to provide some ancient Christian exegetical guideliness concerning the substantive issues of general revelation, and to demonstrate a classic method of inquiry into general revelation" (ibid. 55; bdk. Oden, "The Long Journey Home," 79-83). Oden juga menjadi editor umum dari The Ancient Christian Commentary on Scripture (ACCS), sebuah rangkaian tafsiran patristik mulai dari Kejadian sampai Wahyu setebal 28 volume. Tafsiran ini meliputi tujuh abad pertama dari sejarah gereja sejak zaman Clement of Rome (1.k. 95 M) sampai dengan John of Damascus (l.k. 645-749 M) (lih. Thomas C. Oden, The Ancient Christian Commentary on Scripture, 28 vols; gen. ed. Thomas C. Oden; [Downers Grove: InterVarsity, 2001], 1. xi).

${ }^{15}$ Thomas C. Oden, Pastoral Theology: Essentials of Ministry (New York: HarperSanFransisco, 1983), vii; Thomas C. Oden, Care of Souls in the Classic Tradition, ed. Don Browning; (Philadelphia: Fortress, 1984), 12; dan Thomas C. Oden, Classical Pastoral Care, 4 vols; (Grand Rapids: Baker, 1987), 1. 5; bdk. Thomas C. Oden, "The Historic Pastoral Care Tradition: A Resource for Christian Psychologists," Journal of Psychology and Theology 20, no. 2 (Summer 1992): 137-146.

${ }^{16}$ The Living God, 5.

${ }^{17}$ Ibid., 1. intellectum."18 Bagi Oden, harmoni imanrasio dalam teologi bukanlah penemuan baru, tetapi warisan dari teologi patristik. ${ }^{19}$

Hal lain yang menarik perhatian dalam sistematika Oden ialah bahwa teologi haruslah dilakukan dalam konteks komunitas sejarah Kristen, bukan individu. ${ }^{20}$ Oden menyatakan maksudnya demikian:

Classic Christian thinking can be grasped by contemporary critical minds - even those who may resist fiercely at first - especially if they can learn to think historically with a community, rather than individualistically. Only when each one hears his or her own individual experience illuminated by the wisdom of the historical Christian communities it then possible to contribute that illuminated personal experience back to the community. ${ }^{21}$

Bagi Oden, teologi bukanlah sekadar sebuah refleksi iman yang bersifat pribadi, betapapun inovatifnya. Teologi harus kembali kepada konteks komunitas sejarah Kristen yang menjadi "pagar dialektika teologis." 22 Karena "God has left a trail of language behind a stormy path of historical activities," 23 tugas teologi ialah menyuarakan kembali "bahasa" tersebut dalam gema yang sama sebagaimana pertama kali "bahasa" itu diperdengarkan. Ini yang Oden lakukan dalam teologi sistematikanya.

Dalam ranah biblika, semangat kembali kepada tulisan patristik Oden tunjukkan dalam banyak tulisannya, salah satunya dalam artikel "Without Excuse: Classic Christian Exegesis of General Revelation." Berpijak

\footnotetext{
${ }^{18}$ Oden mengatakan bahwa "the Christian study of God is a faith seeking understanding” (ibid., 25).

${ }^{19}$ Ibid., 1.

${ }^{20}$ Ibid.; bdk. Bishop Hilarion Alfeyev, "The Faith of the Fathers: The Patristic Background of the Orthodox Faith and the Study of the Fathers on the Treshold of the $21^{\text {st }}$ Century," St. Vladimir's Theological Quarterly 51, no. 4 (2007): 371-393.
}

${ }^{21}$ The Living God, 1-2. Penekanan oleh penulis.

${ }^{22}$ Bandingkan konsep "consensus patrum" dalam Alfeyev, "The Faith of the Fathers," 374-379.

${ }^{23}$ The Living God, 3. 
pada metode eksegesis patristik, Oden meneliti Roma 1:18-22 tentang wahyu umum. Kontribusi Oden dalam tulisan ini terlihat dalam dua hal: pertama, Oden menunjukkan bahwa konsep wahyu umum bukanlah temuan Luther dan Calvin, melainkan konsep yang lahir dari konsensus tulisan patristik:; kedua, Oden menunjukkan bahwa metode penafsiran patristik dapat digunakan untuk menyatukan berbagai pandangan yang berbeda tentang isu teologis tertentu, dalam hal ini wahyu umum..$^{25}$

Usaha yang lebih komprehensif untuk kembali kepada tulisan patristik Oden lakukan dengan mengedit Ancient Christian Commentary on Scripture (ACCS). Salah satu keunikan ACCS ialah bagaimana teks PL dibaca dengan konsepsi teologis PB. Misalnya, dalam bagian overview Kejadian, ACCS tanpa ragu langsung menyajikan pandangan Agustinus, Origen, dan Chrysostom tentang Kejadian 1:1 yang mengatakan bahwa "God created heaven and earth through the Word, since 'in the beginning was the Word' (Augustine). God made heaven and earth in the beginning, not in the beginning of time but in Christ (Origen, Chrysostom, Augustine)."26 Suara patristik bergema di sepanjang tafsiran ini. Oden mengakui,

The Ancient Christian Commentary on Scripture has three goals: the renewal of Christian preaching based on classical Christian exegesis, the intensified study of Scripture by

\footnotetext{
${ }^{24}$ Mengenai wahyu umum, Oden menilai bahwa "this consensus is clearly found in the earliest written Christian recollections of the meaning of Paul's letter. It was a maturing exegesis in the second and third centuries and was maturely stated in the fourth century and the following" ("Without Excuse," 68).

${ }^{25}$ Oden menambahkan bahwa "in time it became appropriated and reconfirmed by Luther, Calvin, Wesley, and North American evangelical revivalism as rightly and thoroughly grounded in Scripture" (ibid.; bdk. Thomas C. Oden, "Faith and Hope for the Future," Evangelical Review of Theology 20, no. 4 [October 1996]: 292-311 dan "Faith and Hope for the Future: Towards A Vital and Coherent Evangelical Theology for the $21^{\text {st }}$ Century, Summary Reports of the Working Groups," Evangelical Review of Theology 21, no. 1 [January 1997]: 5-7, 18-21).
}

\footnotetext{
${ }^{26}$ Ancient Christian Commentary, 1.
}

lay persons who wish to think with the early church about the canonical text, and the stimulation of Christian historical, biblical, theological and pastoral scholarship toward further inquiry into the scriptural interpretations of the ancient Christian writers. ${ }^{27}$

Kerinduan utama Oden ialah bahwa pemahaman patristik tentang Alkitab akan mewarnai mimbar gereja, refleksi pribadi, dan studi kesarjanaan yang menyuarakan kebenaran komunitas awal para penafsir Alkitab.

Usaha untuk kembali kepada tulisan patristik juga tampak dalam ranah pastoral. Bagi Oden, prinsip-prinsip pastoral harus kembali kepada prinsip-prinsip yang diletakkan oleh tulisan patristik. Pada tahun 1984, Oden menulis Care of Souls in the Classic Tradition. Tulisan ini berusaha menunjukkan integrasi, bukan hanya antara teologi dan psikologi, tetapi antara teologi pastoral dengan teologi patristik. Oden melakukan ini karena "pastoral care has often been practiced in our time with narrow unhistorical, or even anti-historical assumption and prejudices." 28 Yang Oden maksudkan dengan "unhistorical" dan "antihistorical" ialah bahwa sering kali teologi pastoral (dan juga pendekatan integrasi antara teologi dan psikologi) dilakukan tanpa mempertimbangkan suara patristik dalam sejarah gereja. ${ }^{29}$ Pendekatan yang umumnya mendominasi ialah dari perspektif modern, bahkan perspektif modern yang non-Kristen, misalnya "Sigmund Freud, Fritz Perls, Carl Rogers, Eric Berne, et al." 30 Dengan tegas Oden mengatakan bahwa sudah saatnya gereja mendengarkan suara patristik dalam ranah pastoral. $^{31}$

\footnotetext{
${ }^{27}$ Ibid., xi.

${ }^{28}$ Classical Pastoral Care, 7.

${ }^{29}$ Ibid.
}

${ }^{30}$ Oden menilai bahwa "these psychologists have at times tended to demean and undercut potential dialogue with classical sources, and foreclosed any recognition of any need for awareness of them" (ibid.).

${ }^{31}$ Menurut Oden, "although modern pastors do well to read these psychologists, their views are not normative for pastoral care.... It is time to give classical views a new hearing" (ibid.). 
Tiga tahun kemudian, 1987, Oden menulis buku panduan teologi pastoral yang lebih komprehensif berjudul Classical Pastoral Care setebal empat volume. Oden menegaskan perspektifnya demikian:

Classical pastoral care is pastoral care as understood, practiced and set forth by key writers of the Christian tradition. That is classical which is versed in classics. Classics are the works of highest rank and quality in a field of study, whose worth has been recognized over a long period of time. ${ }^{32}$

Teologi pastoral klasik adalah teologi pastoral yang berpijak pada warisan sejarah kekristenan mula-mula, yang Oden nilai sebagai "the works of highest rank and quality" dan "gem-like quality."33 Di dalamnya, Oden menyoroti konsep menjadi seorang gembala, pelayanan melalui firman dan sakramen, konseling pastoral, dan berbagai pelayanan krisis; seluruhnya dari perspektif patristik. Melaluinya, Oden mengajak para gembala dan teolog untuk meredefinisi teologi pastoral dalam konteks patristik sebagai bagian dari komunitas sejarah Kristen. ${ }^{34}$

Bagi Oden, semangat kembali kepada tulisan patristik bukan hanya harus dilakukan dalam lingkup praktisi, tetapi juga lingkup akademisi pastoral. Pada tahun 1992, Oden menembus lingkaran akademis Journal of Psychology and Theology melalui artikel "The Historic Pastoral Care Tradition: A Resource for Christian Psychologists." Lagi-lagi Oden menyuarakan hal yang sama, yaitu kembali kepada tulisan patristik. Ia mengingatkan,

Long before psychology was a distinct profession, Christian pastors and spiritual advisors were engaged daily in activities that required what is viewed today as psychological expertise or wisdom. Many essential elements of therapeutic care were well understood before the modern period..$^{35}$

\footnotetext{
${ }^{32}$ Ibid., 5.

${ }^{33}$ Ibid.

${ }^{34}$ Ibid.

35“"The Historic Pastoral Care Tradition,” 137.
}

Melalui tulisan ini, Oden mengajak para akademisi pastoral, psikiater, dan psikolog Kristen untuk menyadari bahwa apa yang disebut sebagai keterampilan psikologis pada masa kini sebenarnya sudah dilakukan jauh-jauh hari oleh para bapa gereja. Hikmat patristik seharusnya menjadi salah satu sumber utama dalam teologi pastoral yang sehat.

\section{Berakar pada Warisan Sejarah Kekristenan Afrika Awal}

Metode berteologi kedua yang Oden tunjukkan dalam banyak tulisannya ialah kesadaran bahwa kekristenan masa kini memiliki warisan sejarah yang berakar pada kekristenan Afrika awal. Kekristenan umumnya identik dengan agama dan teologi yang berasal dari Barat. ${ }^{36}$ Oden tidak sependapat dengan hal ini. Ia mengamati bahwa kekristenan memiliki warisan sejarah yang jauh sebelum kekristenan muncul di Eropa atau pun Amerika. ${ }^{37}$ Oden mengajak para peneliti teologi untuk mengarahkan pandangan ke benua Afrika awal. ${ }^{38}$ Yang Oden maksud dengan "Afrika" di sini berbeda dengan konsep Afrika masa kini. $^{39}$ Afrika awal menurut penelitian Oden meliputi area yang jauh lebih luas daripada yang ada sekarang ini. ${ }^{40}$ Kekristenan Afrika awal meliputi,

... all the early forms of Christianity in the first millennium in the four billions of square miles of Egypt, Sudan, Ethiopia, Eritrea, Libya, Tunisia, Algeria and Morocco, and

${ }^{36}$ Yang dimaksud dengan "Barat" di sini mencakup kekristenan di Eropa dan Amerika (lih. Thomas C. Oden, How Africa Shaped the Christian Mind: Rediscovering the African Seedbed of Western Christianity [Downers Grove: InterVarsity, 2007], 9).

${ }^{37}$ Lih. Thomas C. Oden, "Apostolicity and Ethnicity in Early Libyan Christianity," Bibliotheca Sacra 167, no. 666 (April-June 2010): 131-143.

38"A Libyan History Awaiting Discovery," Bibliotheca Sacra 167, no. 665 (January-March 2010): 3-16.

39،"Early Libyan Christianity from Marmarica to Tripolitania,” Bibliotheca Sacra 167, no. 667 (July-September 2010): 259-280.

\footnotetext{
40"The Significance of Early Libyan Christianity," Bibliotheca Sacra 167, no. 668 (October-December 2010): 387-403.
} 
possibly further south than we now know. The geography of the continent shaped the fact that African Christianity first appeared north of the Sahara in the first millennium, and then its second millennium saw exponential growth in the south. Both north and south have been blessed by an enduring heritage of centuries of classic Christianity. ${ }^{41}$

Pada milenium pertama, kekristenan bertumbuh di bagian utara Afrika dan mulai tersebar ke bagian selatan pada milenium berikutnya. Yang Oden maksudkan dengan milenium pertama ialah sejarah kekristenan yang dimulai sejak kelahiran Yesus Kristus.

Injil Matius mencatat bahwa Yusuf, Maria, dan bayi Yesus pernah mengungsi ke Mesir (Mat. 2:13-15). Karena Mesir merupakan bagian dari Afrika, Oden melihat hal ini sebagai titik awal sejarah kekristenan di Afrika. Sejarah kekristenan Afrika berlanjut pada peristiwa Pentakosta di mana Diaspora Yahudi berkumpul di Yerusalem dan mengalami pertobatan melalui khotbah Petrus (bdk. Kis. 2:9-10). Beberapa dari mereka berasal dari Afrika. ${ }^{42}$ Kemudian, catatan sejarah Lukas menunjukkan pertobatan sida-sida dari Etiopia (Kis. 8:26-40). Menimbang Etiopia adalah bagian dari Afrika, Oden menilai hal ini merupakan bagian dari kekristenan awal di sana. Tradisi Libya, menurut Oden, menyaksikan bahwa Markus mati sebagai martir di Aleksandria, Mesir. ${ }^{43}$ Kemudian Eusebius menempatkan Annianus sebagai penerus Markus di Aleksandria. ${ }^{44}$

Sejarah kekristenan mula-mula juga menceritakan bagaimana kekristenan berkembang pesat di Afrika dengan kemunculan tokohtokoh Kristen terkemuka seperti Tertulianus (dari Kartago, Tunisia), Klemens (dari

${ }^{41}$ Oden, How Africa Shaped the Christian Mind, 13.

${ }^{42}$ Ibid., 158. Yaitu dari Mesir dan daerah-daerah Libya yang berdekatan dengan Kirene.

${ }^{43}$ Ibid., 159; bdk. Thomas C. Oden, African Memory of Mark: Reassesing Early Church Tradition (Downers Grove: InterVarsity, 2011), 10-11.

${ }^{44}$ Oden, How Africa Shaped the Christian Mind, 159; Oden, African Memory of Mark, 11.
Aleksandria), Cyprianus (dari Kartago), Origenes (dididik dalam sekolah katekisasi di Aleksandria), Athanasius (dari Aleksandria) ${ }^{45}$ dan tentu saja, Agustinus (dari Tagaste, Algeria). ${ }^{46}$ Menurut Oden, nama-nama ini hanyalah sekelumit contoh tentang betapa kayanya warisan iman dan teologi kekristenan di Afrika awal. ${ }^{47}$ Melupakan warisan iman Afrika sama saja dengan melupakan darah martir yang tertumpah demi benih Injil tetap tumbuh subur sampai saat ini. ${ }^{48}$

Lantas apa faedah dari berbagai penelitian ini? Oden melihat minimal ada empat: pertama, teologi Kristen tidak bisa lagi hanya dilihat dari perspektif Barat (dengan warisan skolastiksisme yang begitu kuat). Sebaliknya, teologi Kristen juga harus dilihat dari perspektif Afrika, yaitu bagaimana teologi lahir, tumbuh, dan berkembang di sana. Oden melihat ini nantinya juga berdampak pada studi sejarah gereja; ${ }^{49}$ kedua, warisan iman Kristen mula-mula ini harus diceritakan kepada setiap anak Afrika sebagai "birthright" mereka; ${ }^{50}$ ketiga, tantangan penelitian lebih lanjut terbuka bagi para peneliti teologi, khususnya para teolog Afrika, untuk mengkultivasi kekayaan warisan iman yang selama ini

${ }^{45}$ Menurut dokumen Dair Anba Maqar, orangtua Athanius berasal dari al-Balyyana, Mesir Utara (ibid., 169).

${ }^{46}$ Sampai akhir hayatnya, Agustinus kemudian menjadi uskup di Hippo, yaitu Annaba, di Aljazair, Afrika Utara (ibid.).

${ }^{47}$ Ibid.

${ }^{48}$ Benarlah apa yang Oden katakan bahwa "the rapid spread of early Christianity was due in part to the heartbreaking African history of martyrdom. This is a history of African blood on African soil" (ibid., 117).

${ }^{49}$ Oden menilai bahwa "christianity would not have its present vitality in the Two-Thirds World without the intellectual understandings that developed in Africa between 50-500 C.E. The pretense of studying church history while ignoring African church history is implausible" (ibid., 9-10).

${ }^{50}$ Dengan indah, Oden menegaskan bahwa "All Christians on the continent of Africa have a birthright that awaits their discovery. . . . The story of early African Christianity needs to be told to African children in villages and cities. The story deserves to be told in a simple way. Though it will be heard by a global audience, it first must find a way of reaching the African child" (ibid., 11). 
terabaikan; ${ }^{51}$ dan keempat, penyingkapan sejarah ini memberikan kesempatan untuk komunitas Muslim dan Kristen berdialog dalam konteks warisan iman mereka di Afrika. ${ }^{52}$

\section{Bermuara kepada Penggembalaan}

Bagi Oden, teologi tidak pernah boleh berhenti pada dirinya sendiri. Teologi harus selalu melayani kebutuhan gereja, yaitu bermuara kepada penggembalaan. Inilah metode berteologi Oden yang ketiga. Yang Oden maksud dengan "penggembalaan" ialah kebutuhan untuk mengajar, mendidik, dan membimbing komunitas Kristen mengenai dasar-dasar iman Kristen yang benar. ${ }^{53}$ Poin ini tampak jelas paling tidak dalam dua hal: pertama, bagi Oden, teologi adalah untuk pastor; kedua, teologi harus terintegrasi dengan praktik pastoral.

Pertama, berkaitan dengan teologi adalah untuk pastor, Oden menyatakan,

The center of my target audience is the working pastor. I have wondered whether it is possible to write a systematic study of God that pastors will actually find useful, practical for preaching and pastoral care.... For persons inquiring into Christian faith or preparing for baptism or confirmation, it intends to be a basic summary of Christian teaching. ${ }^{54}$

Menarik sekali bahwa Oden menulis sistematika teologinya bukan sekadar untuk pastor,

\footnotetext{
${ }^{51}$ Menyoroti hal ini, Oden mengatakan bahwa "the challenge that lies ahead for young Africans is to rediscover textual riches of ancient African Christianity. This will call for a generation of African scholars to reevaluate prejudicial assumptions that ignore or demean African intellectual history" (ibid., 9).

${ }^{52}$ Ibid., 134-142. Secara khusus Oden menilai bahwa sejarah relasi dialogis antara Kristen-Islam ini akan bermanfaat bagi perkembangan misi, khususnya dalam konteks dialog dengan Islam (ibid., 134; bdk. Thomas C. Oden, Early Libyan Christianity: Uncovering a North African Tradition [Downers Grove: InterVarsity, 2011], 301-304).
}

${ }^{53} \mathrm{Bdk}$. Thomas Oden, "Pastoral Care and the Unity of Theological Education," Theology Today 42, no. 1 (April 1985): 34-42. Oden berargumen bahwa pendidikan teologi yang benar tidak pernah boleh dilepaskan dari tugas penggembalaan (ibid., 40-41).

${ }^{54}$ The Living God, x-xi. Penekanan oleh penulis. tetapi untuk working pastor. ${ }^{55}$ Ini menjelaskan fokus dari metode berteologi Oden. Baginya, teologi bukanlah untuk konsumsi kaum elit cendekiawan Kristen. Teologi harus mendarat dalam kehidupan sehari-hari. Tidak heran ia menulisnya untuk working pastor. Selain itu, menurut Oden, teologi juga adalah untuk mempersiapkan calon katekumen, yaitu mereka yang akan dibaptis atau menjalani sidi. Oden tidak melihat teologi sekadar diskusi teologis rasional yang memuaskan logika, tetapi ia mengerucutkannya pada fungsi pengajaran dan penggembalaan jemaat. Singkatnya, ia tidak berteologi di "menara gading."

Kedua, kepedulian yang besar untuk mengintegrasikan teologi dan praktik pastoral amat kentara dalam berbagai tulisan Oden. Ini didorong oleh keprihatinan Oden akan teologi pastoral modern yang menurutnya telah "keluar jalur" dari teologi yang ortodoks. Suara Oden tajam mengenai hal ini:

Just as the biblical area has been taken captive by reductionist historical methodologies, as many church and society issues have been taken captive by various reductionist sociological methods, as too much systematic theology has become captive to one after another emergent or passing philosophical method, so pastoral care has become almost irretrievably captive and embarrassingly indebted to reductionistic psychological and psychotherapeutic methods. Often these methods, if taken consistently, would rule out the fundament of Christian pastoral care: that God cares for humanity in Jesus Christ. ${ }^{56}$

Seperti layaknya biblika, teologi pastoral modern sedang berada di bawah bayangbayang prasuposisi psikologi dan psikoterapi modern yang jauh dari kebenaran Alkitab. Bagi Oden, tidak bisa tidak, teologi pastoral harus kembali kepada sistematika yang sehat. Dengan tegas ia menyatakan bahwa "the reintegration of pastoral care into the theological curriculum depends upon the rediscovery of an

\footnotetext{
${ }^{55}$ Bukan sekadar untuk pendeta, tetapi pendeta yang menggembalakan.

56"Pastoral Care," 35.
} 
integrated method of theological study grounded in the classical pastoral writers." ${ }^{57}$ Ini berarti sistematika tidak boleh berdiri untuk dirinya sendiri. Sebaliknya, sistematika harus melayani pastoral. Itulah teladan para teolog patristik. Itulah juga yang Oden lakukan.

\section{Analisis Teologis Metode Berteologi Thomas C. Doen}

Apa yang Oden lakukan dalam metode berteologinya-kembali kepada tulisan patristik, berakar pada warisan sejarah kekristenan Afrika awal, dan bermuara pada penggembalaan-menarik perhatian banyak pihak. Oden sendiri mengakui,

My colleagues think me a little odd. They see me to some degree as nostalgic, or romanticist. The most counter-traditional colleagues interpret me as a little dangerous because they hear me talking about orthodoxy and heresy. They hear me talking about Scripture in its plain sense. And that bothers them a lot because they had been assured that all that talk belonged to a bygone period. ${ }^{58}$

Walaupun dinilai aneh, bahkan berbahaya, Oden tetap "menancap" bahkan lebih dalam lagi pada kekayaan ortodoksi tulisan patristik. Terlepas dari komitmen Oden yang kuat terhadap warisan patristik, metode berteologinya perlu mendapatkan analisis yang proporsional.

\section{Kembali kepada Tulisan Patristik}

Adalah Cornelius Plantinga, Jr., profesor teologi sistematika di Calvin Theological Seminary, yang pertama kali menanggapi tulisan Oden dengan serius. Dalam "Response to Thomas C. Oden, 'The Long Journey Home'," ${ }^{59}$ Plantinga mengapresiasi usaha

\footnotetext{
${ }^{57}$ Ibid.; bdk Thomas C. Oden, "After-Modern Wesleyan Spirituality: Toward A Neo-Wesleyan Critique of Criticism," Ashland Theological Journal 25 (1993): 38-54.

${ }^{58}$ Hall, "Back to the Fathers" http://www.christianitytoday.com/ct/2011/octoberweb-only/back-fathers.html (diakses 2 April 2015).
}

${ }^{59}$ Journal of the Evangelical Theological Society 34, no. 1 (March 1991): 93-96.
Oden untuk kembali kepada akar ortodoksi iman Kristen yang selama ini sering ditinggalkan oleh para teolog modern. ${ }^{60}$ Plantinga melihat Oden seperti "anak yang hilang" namun kini telah kembali ke rumah di mana Oden seharusnya berada. Bagi Plantinga, "it is a pleasure to respond to Tom's Oden long journey home. Once upon a time Tom wasted his substance in riotous thinking in a far country, but he found no soul food there. So Tom has come back where he always belonged." ${ }^{61}$ Plantinga menyambut hangat niat baik Oden yang bukan hanya kembali kepada ortodoksi, tetapi juga ortodoksi patristik. ${ }^{62}$ Selain itu, Plantinga menilai bahwa apa yang Oden lakukan menelanjangi kegagalan yang sering kali dilakukan oleh teolog Injili, yaitu kehausan akan inovasi teologi sampai-sampai mengorbankan semangat ekumenikal dialogis yang mempersatukan. ${ }^{63}$ Plantinga menyoroti demikian:

Tom's theology aims to be irenic and consensually ecumenical, and on both these scores it strikes me as remarkably successful. Theologically, we Christians have been in the habit of defining and defending ourselves as different from other Christians. ... Tom's Oden theology is in exactly this respect centrist Christian theology: irenic, massively traditional, ecumenically attractive, and spiritually vital. ${ }^{64}$

Bagi Plantinga, Oden berhasil untuk tidak menciptakan sebuah teologi baru, tetapi hanya menyuarakan kekayaan yang selama ini tersimpan dalam sejarah gereja awal, yang ia sebut sebagai "irenic." 65 Plantinga juga memuji usaha Oden yang mendorong adanya kesatuan dalam keberbedaan teologi

${ }^{60}$ Ibid., 93.

${ }^{61}$ Ibid.

${ }^{62}$ Plantinga memujinya sebagai "rich, meaty, satisfying theology that is alarmingly learned and yet accesible to students" (ibid., 94).

${ }^{63}$ Ibid., 93.

${ }^{64}$ Ibid.

${ }^{65}$ Ibid. 
dengan cara kembali kepada tulisan patristik. ${ }^{66}$ Menurutnya, ini adalah poin yang baik.

Apresiasi yang sama juga diberikan oleh Daniel B. Clendenin, asisten profesor Alkitab dan teologi di William Tyndale College dalam artikelnya berjudul "Learning to Listen: Thomas C. Oden on Postcritical Orthodoxy." ${ }^{67}$ Clendenin menilai usaha Oden yang membawa teologi kembali kepada tulisan patristik adalah sebuah reformasi dari jerat modernisme. ${ }^{68}$ Ia menyatakan maksudnya bahwa, "Thomas Oden ... prescribed a reformation in the direction of antiquity, a postmodern return to ancient orthodoxy that would leapfrog the recent past of modernity in favor of a normative patristic era." ${ }^{6}$ Tulisan patristik ibarat "resep kuno" yang diharapkan dapat menyembuhkan penyakit teologi karena "virus modernisme."70 Namun tidak semua teolog setuju sepenuhnya dengan metode ini.

Misalnya saja Donald Fairbairn, profesor teologi historis di Erskine Theological Seminary dan Evangelische Theologische Faculteit. ${ }^{71}$ Dalam artikel "Patristic Exegesis and

\footnotetext{
${ }^{66}$ Apa yang Oden lakukan ini mirip dengan semangat ekumenikal teologi global. Simon Chan menyatakan bahwa "the point of my repeated references to Catholicism and Orthodoxy is that a global theology is ultimately a catholic (spelled with a small c) theology" "“The Future of Global Theology: An Asian Perspective," Journal of Asian Evangelical Theology 18/2 [September 2014]: 17). Penekanan oleh penulis.
}

${ }^{67}$ Journal of the Evangelical Theological Society 34, no. 1 (March 1991): 97-102.

${ }^{68}$ Ibid., 97.

${ }^{69}$ Ibid.

${ }^{70}$ Ibid. Yang dimaksud dengan "virus modernisme" di sini ialah prasuposisi modernisme yang menihilkan otoritas Alkitab, mencurigai dengan negatif segala warisan ortodoksi, dan memutlakkan otonomi manusia dalam penelitian teologi (bdk. Thomas C. Oden, Two Worlds: Notes on the Death of Modernity in America \& Russia [Downers Grove: InterVarsity, 1992], 20-47). Oden menentang keras akan hal ini. Menurutnya, "each of these key modern modes of inquiry is now in deep anguish and distress. . . Modernity east and west is in its final crisis of waning strength" (ibid., 38; bandingkan pengamatan serupa yang Oden lakukan dalam Requem: A Lament in Three Movements [Nashville: Abingdon, 1995], 104-136).

\footnotetext{
${ }^{71}$ Masing-masing di Due West, South Carolina dan Leuven, Belgium.
}

Theology: The Cart and the Horse,"72 Fairbairn mensinyalir bahwa dewasa ini terjadi pergerakan minat teologi Injili kepada berbagai tulisan patristik, khususnya dalam konteks penafsiran Alkitab dan formulasi teologi. ${ }^{73}$ Ia menyambut semangat ini dengan positif. Namun hal ini tidak bisa dilakukan dengan mata tertutup, artinya tidak kritis sama sekali. Fairbairn memperingatkan bahwa tulisan patristik tidak selalu memiliki kesepakatan dalam diri mereka sendiri. ${ }^{74}$ Ambil contoh perikop 1 Samuel 28 mengenai Saul di En-Dor. Fairbairn mengamati bahwa Origen menafsirkan ini secara literal historis, ${ }^{75}$ sedangkan Eustathius memaknainya secara alegoris. ${ }^{76}$ Keduanya adalah tulisan patristik. Jika Oden mengatakan untuk kembali kepada tulisan patristik. Pertanyaannya ialah "tulisan patristik yang mana?" Penulis sependapat dengan Fairbairn, ini adalah salah satu masalah bagi metode yang Oden tawarkan.

Masalah yang lain ialah kentalnya muatan filsafat Yunani dalam tulisan patristik. Misalnya pengajaran Origen, khususnya tentang praeksitensi jiwa, sering kali dikaitkan dengan konsep filsafat platonisme. Cyril Wohrer mengamati hal ini demikian:

While various scholars disagree on extent to which Origen embraces the Platonic idea of the pre-existence of the soul, he certainly entertains it. In First Principles, he acknowledges the plausible existence of several successive worlds in which souls who

${ }^{72}$ The Westminster Theological Journal 69, no. 1 (Spring 2007): 1-19.

${ }^{73}$ Fairbairn sendiri menyatakan bahwa "there is a strong and growing interest in patristic interpretation of the Bible among evangelical biblical scholars and theologians" (ibid., 1; bdk pengamatan yang sama dalam Kenneth J. Stewart, "Evangelicalism and Patristic Christianity: 1517 to the Present," Evangelical Quarterly 80, no. 4 [October 2008]: 307-321).

${ }^{74}$ Ibid., 6.

${ }^{75}$ Yaitu bahwa kejadian itu benar-benar terjadi persis seperti yang dituturkan oleh narasi 1 Samuel bahwa perempuan pemanggil arwah itu benar-benar memanggil arwah Samuel yang telah mati (ibid., 6).

${ }^{76}$ Roh jahatlah yang mendatangkan arwah Samuel, bukan perempuan pemanggil arwah itu (ibid.). 
have not achieved the required purification in the present world (as well as those who can potentially "fall" from a state of beatitude) can enter into a physical body. ${ }^{77}$

Memang tidak semua pengajaran Origen berkaitan dengan platonisme. Namun konsepnya tentang pra-eksistensi jiwa dalam beberapa dunia yang berbeda, sedikit banyak merefleksikan ide platonisme tentang pra-eksistensi jiwa. ${ }^{78}$ Hal yang sama juga diamati oleh Ilaria L.E. Ramelli. Menyoroti keterkaitan teologi patristik dan filsafat Yunani, ia bahkan menyimpulkan bahwa "patristic thinkers assimilated Greek philosophy not only for apologetic purposes, but also at the theoretical level; not only on the formal plane ... but clear traces of a substantial co-determination of the theological object." 79 Ramelli menyoroti bahwa konsepsi teologis patristik tidak pernah dapat dilepaskan dari filsafat Yunani. ${ }^{80}$ Bahkan, di atas filsafat Yunani itulah seluruh teologi patristik dibangun. ${ }^{81}$

Inilah yang juga dikhawatirkan oleh Plantinga. Plantinga menilai Oden kurang peka dan kritis dalam mengamati hal ini. Terlepas dari semangat Oden yang positif, Plantinga menilai bahwa "I think it doubtful that we must accept the patristic consensus without question." 82 Sependapat dengan Ramelli, ia mengatakan bahwa "after all, the Church

77، Pop Patristic Reincarnation? A Critique of Origen's Alleged Doctrine of Reincarnation," Religious Studies and Theology 31, no. 1 (2012): 95. Penekanan oleh penulis. Dalam artikel ini, Wohrer berusaha membuktikan bahwa Origen tidak mengajarkan doktrin reinkarnasi sebagaimana yang dituduhkan. Menariknya, Wohrer juga menunjukkan adanya irisan antara konsep Origen tentang jiwa dengan ajaran filsafat platonisme.

${ }^{78}$ Ibid.; bandingkan pengamatan Ilaria L.E. Ramelli tentang hal ini dalam "Origen, Patristic Philosophy, and Christian Platonism: Re-Thinking the Christianisation of Hellenism," Vigiliae Christianae 63, no. 4 (2009): 217-263.

\footnotetext{
79، Origen, Patristic Philosophy, and Christian Platonism," 257. Ramelli melanjutkan bahwa "indeed, it is on the philosophical basis provided by Platonism that the chief dogmata and theologoumena of Christianity arose" (ibid.).

${ }^{80} \mathrm{Ibid}$.

${ }^{81}$ Ibid.

82“"Response to Thomas C. Oden," 95.
}

fathers and mothers knew not only Bible but also philosophy and in particular areas, did not hesitate to shape theories accordingly." 83 Plantinga menasihati bahwa sikap yang baik ialah, "we receive the classical consensus with deep respect and hospitality, but also with a proper Biblical and scholarly reserve." ${ }^{84}$ Dalam hal ini, penulis sependapat dengan Plantinga. Metode Oden yang pertama ini memang berpotensi positif untuk membawa arah teologi kepada ortodoksi dan semangat ekumenikal patristik. Namun, teologi patristik juga bukan tanpa masalah karena adanya perbedaan pandangan dan muatan pengaruh filsafat Yunani.

\section{Berakar pada Warisan Sejarah Kekristenan Afrika Awal}

Metode Oden yang kedua menuai lebih banyak pujian alih-alih kritikan. J. Scott Horrell, dari Dallas Theological Seminary, mengatakan bahwa dengan menunjukkan warisan sejarah kekristenan Afrika awal, Oden berhasil menunjukkan kontribusi kekristenan Afrika. ${ }^{85}$ Penemuan ini juga membelalakkan mata dunia, khususnya dunia Barat, untuk mengakui warisan kekayaan Afrika, bukan hanya secara teologis tetapi juga intelektual. Horrell mengingatkan bahwa "it is easily forgotten that Alexandria was once the intellectual center of the world and a major location for both Jewish and Christian populations." ${ }^{66}$ Apresiasi serupa juga datang dari Jehu J. Hanciles, profesor

${ }^{83}$ Ibid.

${ }^{84}$ Ibid.

${ }^{85}$ Khususnya dalam tujuh hal, yaitu: (1) konsep Barat tentang universitas, (2) eksegesis Kitab Suci, (3) doktrin awal Kristen, (4) pola pengambilan keputusan dalam lingkup ekumenikal, (5) kelahiran dan perkembangan monastisime, (6) neoplatonisme Kristen, dan (7) perkembangan dari retorika dan dialektika finesse. Poin satu, empat, dan tujuh relatif baru dalam studi sejarah kekristenan, khususnya dalam konteks Afrika ("Book Reviews, How Africa Shaped the Christian Mind: Rediscovering the Africa Seedbed of Western Christianity by Thomas C. Oden," Bibliotheca Sacra 167, no. 665 [January-March 2010]: 112).

\footnotetext{
${ }^{86}$ Ibid.; bdk. Kevin L. Hester, "Book Reviews, How Africa Shaped the Christian Mind: Rediscovering the Africa Seedbed of Western Christianity by Thomas C. Oden," Journal of the Evangelical Theological Society 52, no. 1 (March 2009): 191-195.
} 
sejarah misi dan globalisasi pada departemen studi lintas budaya di Fuller Theological Seminary. Hanciles mengatakan bahwa "by the end of the twentieth century, as all now recognize, dramatic shifts within global Christianity saw Africa emerge as a major heartland of the faith and African Christianity as a prominent representation of Christianity's nature and prospects." 87 Dengan menunjukkan akar warisan sejarah kekristenan di Afrika, Oden berhasil menarik perhatian dunia kepada Afrika, bukan hanya sebagai jati diri awal, tetapi juga sebagai masa depan kekristenan. ${ }^{88}$

Terlepas dari apresiasi yang diterima, metode Oden ini mendapatkan sorotan negatif dari Andrew E. Barnes yang mengatakan bahwa metode Oden ini memiliki dua kelemahan yang besar. ${ }^{89}$ Pertama, Oden kurang menyajikan bukti-bukti historis dalam penggunaan metodenya ini..$^{90}$ Tulisan-tulisannya yang berkaitan dengan sejarah Afrika hampir tidak memuat catatan kaki. Barnes melihat hal ini agak bermasalah bagi penelitian kesarjanaan. ${ }^{91}$ Kedua, Barnes menilai metode Oden ini lemah bagi dialog Muslim-Kristen karena mayoritas penduduk Afrika adalah Muslim saat ini. ${ }^{92}$ Barnes tidak terlalu melihat faedah yang dapat dipetik dari dialog yang "tidak

\footnotetext{
87"Book Reviews, How Africa Shaped the Christian Mind: Rediscovering the Africa Seedbed of Western Christianity by Thomas C. Oden," International Bulletin of Missionary Research 32, no. 4 (2008): 210.
}

${ }^{88}$ Bdk. John Bolt, "Evangelical Ecclesiology: No Longer An Oxymoron?," Calvin Theological Journal 39, no. 2 (2004): 400-411. Bolt menilai apa yang Oden lakukan memberi kontribusi signifikan terhadap usaha pembentukan semangat eklesiologi Injili dalam konteks ekumenikal.

89"Book Reviews, How Africa Shaped the Christian Mind: Rediscovering the Africa Seedbed of Western Christianity by Thomas C. Oden," Church History 77, no. 4 (2008): 1108-1110.

\footnotetext{
${ }^{90}$ Barnes mengatakan bahwa "the great weakness of Oden's ideas is the thinness of evidence upon which they are constructed" (ibid., 1110).

${ }^{91}$ Ibid.

${ }^{92}$ Barnes menyoroti bahwa "the lands where early African Christianity thrived are now for the most part Muslim" (ibid.).
}

setara ini."93 Apa yang Barnes katakan ada benarnya, tetapi hal itu tidak meniadakan kontribusi Oden dalam lingkup kesarjanaan. Lagi pula, sumber pustaka yang Oden sajikan cukup memadai sebagai penelitian akademis.

\section{Bermuara kepada Penggembalaan}

Mengenai metode yang ketiga, Oden melakukan apa yang John Calvin pernah lakukan dalam tujuan penulisan Institutio-nya. Calvin mengatakan:

My intention was only to furnish a kind of rudiments, by which those who feel some interest in religion might be trained to true godliness. And I toiled at the task chiefly for the sake of my countrymen the French, multitudes of whom I perceived to be hungering and thirsting after Christ. ${ }^{94}$

Tujuan Calvin menuangkan pemikiran teologisnya semata-mata ialah untuk penggembalaan, yaitu mengajarkan firman demi memuaskan mereka yang lapar dan haus akan kebenaran Kristus. Clendenin menyatakan bahwa Oden berhasil menangkap semangat yang mulia ini. ${ }^{95}$ Itulah sebabnya Oden menuliskan proposisi-proposisi teologisnya untuk tujuan pastoral.

Sepakat dengan Clendenin, penulis menimbang ini adalah hal yang sangat baik karena dengan demikian Oden tidak membuat dikotomi pastor-theologian. ${ }^{96}$ Sebaliknya, Oden mengharmoniskannya dalam satu nada panggilan ilahi dalam metode berteologinya ini. ${ }^{97}$ Penulis juga sepakat dengan Plantinga yang menyoroti bahwa metode Oden ini menunjukkan attitude yang tepat dalam berteologi, yaitu kerinduan untuk membawa jemaat pada

${ }^{93}$ Ibid.

${ }^{94}$ Institutes of the Christian Religion, terj. Henry Beveridge; (Grand Rapids: Eerdmans, 1989), 3. Penekanan oleh penulis.

95“Learning to Listen," 100.

\footnotetext{
${ }^{96}$ Clendenin mengamati bahwa Oden menaruh perhatian yang besar pada kebutuhan pastoral dalam tulisantulisan teologisnya (ibid., 99).

${ }^{97}$ Ibid.
} 
kekudusan hidup. ${ }^{98}$ Sebuah attitude yang langka ditemukan dalam konteks kesarjanaan teologi abad ini. ${ }^{99}$

\section{Penutup}

Analisis teologis yang penulis lakukan menunjukkan bahwa ketiga metode berteologi Oden masing-masing memiliki kekuatan dan kelemahannya sendiri. Pertama, menurut hemat penulis, kembali kepada tulisan patristik adalah metode yang tepat dalam berteologi (Plantinga dan Clendenin) karena ortodoksi terpelihara dalam tradisi patristik. ${ }^{100}$ Selain itu, ortodoksi tidak bisa dilepaskan dari kesatuan tradisi patristik-kitab Suci. ${ }^{101}$ Namun metode ini perlu disertai dengan pendekatan yang kritis (Plantinga). Mengingat muatan filsafat Yunani yang kental dalam pemikiran patristik (Wohrer, Ramelli, dan Plantinga), adalah penting untuk membawa tulisan-tulisan patristik dalam dialog satu dengan yang lain sambil terus mengkajinya di bawah terang firman Tuhan (Fairbairn). Di samping itu, Oden tetap perlu mendengarkan "suara" eksegesis masa kini sebagai bagian dari komunitas penafsir yang am. Kedua, warisan sejarah kekristenan di Afrika membuka lembaran baru bagi penelitian lebih lanjut dalam berbagai disiplin ilmu yang relevan. ${ }^{102}$ Penulis melihat potensi pros-

\footnotetext{
${ }^{98}$ Sebuah sikap yang Plantinga sebut sebagai "the groaning of holy desires" ("Response to Thomas C. Oden," 95).

${ }^{99}$ Ibid., 96.

${ }^{100}$ Alfeyef melihat ini dengan baik sekali bahwa "no one will change the need for preserving the patristic legacy. . . . The Fathers have preserved Holy Tradition for us" (Alfeyev, "The Faith of the Fathers," 372). Penekanan oleh penulis.

${ }^{101}$ Ibid.; bdk. Paul Hartog, "The 'Rule of Faith' and Patristic Biblical Exegesis," Trinity Journal 28/1 (Spring 2007): 65-86; dan khususnya Daniel H. Williams, "The Patristic Tradition as Canon," Perspectives in Religious Studies 32/4 (Winter 2005): 357-379. Williams menyatakan bahwa "from the days of the patristic era and for most of the Middle Ages, the tradition and Scripture formed not two, but one mutually inclusive authority on which theologians drew their conclusions" ("The Patristic Tradition," 361).
}

\footnotetext{
${ }^{102}$ Senada dengan hal ini, James A. De Jong mengatakan bahwa penelitian Oden "makes a compelling case for giving the subject fuller, more serious attention than it has
}

pektif dari penelitian Oden, yaitu kontribusi kesarjanaan Oden yang amat besar dalam menunjukkan warisan kekayaan iman Kristen di tanah Afrika. Ini disebabkan karena walaupun Oden umumnya tidak menyajikan catatan kaki, Oden menyediakan daftar pustaka yang berlimpah dalam banyak tulisannya (kontra Barnes). Ketiga, sikap Oden yang mengerucutkan teologi demi fungsi penggembalaan adalah sikap yang sepenuhnya harus diteladani (Clendenin, Plantinga, dan tentunya Calvin!). Semangatnya yang mendasarkan teologi pastoral di atas sistematika patristik kiranya memotivasi penelitian lebih lanjut dalam bidang yang bersangkutan.

Akhirnya, ketika banyak peneliti teologi cenderung berkiprah di "jalan raya" teologi yang prospektif, Oden memilih "jalan setapak" retrospektif yang sunyi. Namun, Oden tidak berjalan sendirian. Ia ditemani oleh Ignatius, Tertulianus, Athanasius, Origen, Agustinus, dan masih banyak bapa gereja lainnya. The Long Journey Home adalah sebuah perjalanan panjang untuk kembali kepada ortodoksi patristik. Sebuah perjalanan yang layak dijalani seumur hidup oleh setiap teolog, oleh setiap anak Tuhan.

gotten in the past" ("Book Reviews, Early Libyan Christianity: Uncovering a North African Tradition by Thomas C. Oden," Calvin Theological Journal 49, no. 2 [November 2014]: 349). 


\section{Daftar Kepustakaan}

Alfeyev, Bishop H. "The Faith of the Fathers: The Patristic Background of the Orthodox Faith and the Study of the Fathers on the Treshold of the $21^{\text {st }}$ Century." St. Vladimir's Theological Quarterly 51, no. 4 (2007): 371-393.

Allen, Paul L. Theological Method: A Guide for the Perplexed. London: T\&T Clark, 2012.

Barnes, Andrew E. "Book Reviews, How Africa Shaped the Christian Mind: Rediscovering the Africa Seedbed of Western Christianity by Thomas C. Oden." Church History 77, no. 4 (2008): 1108-1110.

Bolt, John. "Evangelical Ecclesiology: No Longer An Oxymoron?" Calvin Theological Journal 39, no. 2 (2004): 400-411.

Calvin, John. Institutes of the Christian Religion. Grand Rapids: Eerdmans, 1989.

Chan, Simon. "The Future of Global Theology: An Asian Perspective.” Journal of Asian Evangelical Theology 18, no. 2 (September 2014): 7-20.

Clark, David K. To Know and Love God. Diedit oleh John S. Feinberg. Wheaton: Crossway, 2003.

Clendenin, Daniel B. "Learning to Listen: Thomas C. Oden on Postcritical Orthodoxy." Journal of the Evangelical Theological Society 34, no. 1 (March 1991): 97-102.

Fairbairn, Donald. "Patristic Exegesis and Theology: The Cart and the Horse." The Westminster Theological Journal 69, no. 1 (Spring 2007): 1-19.

Hall, Christopher A. "Introduction." Dalam Ancient \& Postmodern Christianity: Paleo-Orthodoxy in the $21^{\text {st }}$ Century. Eds. Kenneth Tanner and Christopher A. Hall, 7-12. Downers: InterVarsity, 2002.

Hanciles, Jehu J. "Book Reviews, How Africa Shaped the Christian Mind: Rediscovering the Africa Seedbed of Western Christianity by Thomas C. Oden." International Bulletin of Missionary Research 32, no. 4 (2008): 210.

Hester, Kevin L. "Book Reviews, How Africa Shaped the Christian Mind: Rediscovering the Africa Seedbed of Western Christianity by Thomas C. Oden." Journal of the Evangelical Theological Society 52, no. 1 (March 2009): 191-195.

Horrell, J. Scott. "Book Reviews, How Africa Shaped the Christian Mind: Rediscovering the Africa Seedbed of Western Christianity by Thomas C. Oden." Bibliotheca Sacra 167, no. 665 (January-March 2010): 112-113.

Jong, James A. De. "Book Reviews, Early Libyan Christianity: Uncovering a North African Tradition by Thomas C. Oden." Calvin Theological Journal 49, no. 2 (November 2014): 347-349.

Oden, Thomas C. Pastoral Theology: Essentials of Ministry. New York: HarperSanFransisco, 1983. . Care of Souls in the Classic Tradition. Philadelphia: Fortress, 1984.

. "Pastoral Care and the Unity of Theological Education." Theology Today 42, no. 1 (April 1985): 34-42.

. Classical Pastoral Care. Grand Rapids: Baker, 1987. 
. The Living God. New York: Harper \& Row, 1987.

. "The Long Journey Home.” Journal of the Evangelical Theological Society 34, no. 1 (March 1991): 77-92.

. Two Worlds: Notes on the Death of Modernity in America \& Russia. Downers Grove: InterVarsity, 1992.

. "The Historic Pastoral Care Tradition: A Resource for Christian Psychologists." Journal of Psychology and Theology 20, no. 2 (Summer 1992): 137-146.

. "After-Modern Wesleyan Spirituality: Toward A Neo-Wesleyan Critique of Criticism." Ashland Theological Journal 25 (1993): 38-54.

. Requem: A Lament in Three Movements. Nashville: Abingdon, 1995.

. "Faith and Hope for the Future." Evangelical Review of Theology 20, no. 4 (October 1996): 292-311.

. "Faith and Hope for the Future: Towards A Vital and Coherent Evangelical Theology for the $21^{\text {st }}$ Century, Summary Reports of the Working Groups." Evangelical Review of Theology 21, no. 1 (January 1997): 18-21.

. "Without Excuse: Classic Christian Exegesis of General Revelation." Journal of the Evangelical Theological Society 41, no. 1 (March 1998): 55-68.

. The Ancient Christian Commentary on Scripture. Downers Grove: InterVarsity, 2001.

. "On Women and Men Working Together in the Church: Who Will Lead Us? Surely the One Whom the Spirit Gifts.” Evangelical Review of Theology 26, no. 2 (April 2002): 119-135.

. How Africa Shaped the Christian Mind: Rediscovering the African Seedbed of Western Christianity. Downers Grove: InterVarsity, 2007.

. The Good Works Reader. Grand Rapids: Eerdmans, 2007. 2010): 3-16.

. "A Libyan History Awaiting Discovery.” Bibliotheca Sacra 167, no. 665 (January-March

. "Apostolicity and Ethnicity in Early Libyan Christianity." Bibliotheca Sacra 167, no. 666 (April-June 2010): 131-143.

. "Early Libyan Christianity from Marmarica to Tripolitania," Bibliotheca Sacra 167, no. 667 (July-September 2010): 259-280.

. "The Significance of Early Libyan Christianity." Bibliotheca Sacra 167, no. 668 (October-December 2010): 387-403.

. Early Libyan Christianity: Uncovering a North African Tradition. Downers Grove: InterVarsity, 2011.

Plantinga, Jr. Cornelius. "Response to Thomas C. Oden, 'The Long Journey Home'.” Journal of the Evangelical Theological Society 34, no. 1 (March 1991): 93-96.

Ramelli, Ilaria L.E. "Origen, Patristic Philosophy, and Christian Platonism: Re-Thinking the Christianisation of Hellenism." Vigiliae Christianae 63, no. 4 (2009): 217-263. 
Stewart, Kenneth J. "Evangelicalism and Patristic Christianity: 1517 to the Present." Evangelical Quarterly 80, no. 4 (October 2008): 307-321.

Wohrer, Cyril. "Pop Patristic Reincarnation? A Critique of Origen's Alleged Doctrine of Reincarnation." Religious Studies and Theology 31, no. 1 (2012): 91-103. 